\title{
Pengembangan Modul Fisika Materi Momentum dan Impuls Berbasis Metakognisi untuk Siswa Kelas XI SMA PGRI Tanjung Pandan Belitung
}

\author{
Erwinsyah \\ Pendidikan Fisika Universitas Ahmad Dahlan \\ J1. Prof. Dr. Supomo, S.H. Warungboto Yogyakarta \\ Surat-e:
}

\begin{abstract}
Modul fisika berbasis metakognisi masih kurang digunakan dalam kegiatan belajar mengajar. Padahal modul fisika materi momentum, impuls, dan hukum kekekalan momentum berbasis metakognisi sangat dibutuhkan dalam proses belajar mengajar. Modul fisika ini dimaksudkan untuk membantu guru dalam menerapkan metakognisi pada kegiatan belajar mengajar, mengatasi keterbatasan ruang dan waktu. Tujuan penelitian ini adalah I) menghasilkan modul fisika materi momentum dan impuls berbasis metakognisi, 2) mengetahui kualitas modul fisika materi momentum dan impuls berbasis metakognisi yang dikembangkan.

Penelitian pengembangan modul fisika ini sesuai dengan langkah-langkah Research and Development $(R \& D)$. Langkah-langkah yang dilalui meliputi dua aspek yaitu pengembangan modul dan kelayakan. Pengembangan modul meliputi: I) potensi dan masalah; 2) pengumpulan data; 3) desain produk; 4) validasi produk; 5) revisi desain. Kemudian kelayakan modul meliputi: I) uji coba produk; dan 2) revisi desain. Subjek peneliti adalah ahli materi fisika, ahli media, guru fisika SMA kelas XI, dan siswa kelas XI SMA/MA.

Hasil penelitian ini adalah: I) telah dihasilkan modul fisika materi momentum, impuls dan hukum kekekalan momentum berbasis metakognisi; 2) kualitas modul fisika materi momentum, impuls dan hukum kekekalan momentum berbasis metakognisi adalah sangat baik (SB) dengan persentase $80,62 \%$ berdasarkan penilaian ahli materi, berdasarkan ahli media 81,25\%, berdasarkan guru fisika SMA kelas XI 77,78\% dan berdasarkan uji pengguna (siswa) dengan persentase $87,36 \%$. Berdasarkan penilaian tersebut, maka modul fisika materi momentum dan impuls berbasis metakognisi yang telah dikembangkan layak digunakan di dalam proses belajar mengajar.
\end{abstract}

Kata kunci: Modul Fisika Berbasis Metakognisi, Momentum dan Impuls

\section{Pendahuluan}

Reformasi pendidikan yang diawali dengan kebijakan otonomisasi pada satuan pendidikan, dan berujung pada perluasan kewenangan guru dalam mengembangkan pembelajaran yang digerakkan sejak akhir abad ke-20 telah berpenetrasi pada semua aspek pendidikan, bahkan PP No. I9 tahun 2005, tentang Standar Nasional Pendidikan (SNP), mengamanahkan untuk dilakukan standarisasi delapan aspek pendidikan, yakni isi kurikulum, rumusan kompetensi lulusan, pendidik dan tenaga kependidikan, proses pembelajaran, sarana dan prasarana pendidikan, pembiayaan, penilaian dan pengelolaan [I]. Sumber belajar adalah segala sesuatu atau daya yang dapat dimanfaatkan oleh guru, baik secara terpisah maupun gabungan untuk kepentingnan belajar mengajar dengan tujuan meningkatkan efektivitas dan efisiensi tujuan pembelajaran [2].

Hasil wawancara terhadap guru fisika SMA PGRI Tanjung Pandan Belitung menunjukkan bahwa proses belajar mengajar fisika di kelas belum menerapkan upaya pengenalan metakognisi. Menurut guru metakognisi merupakan hal yang sulit di terapkan di dalam proses belajar mengajar, dikarenakan tuntutan yang diberikan kepada guru agar mampu membawa siswa mencapi target ketuntasan materi fisika, sedangkan waktu belajar tatap muka di dalam kelas sangat sedikit. Sehingga, kegiatan belajar mengajar seringkali didominasi dengan cara memberikan informasi materi sebanyak-banyaknya kepada siswa tanpa harus mengetahui siswa paham atau tidaknya.

Salah satu bahan ajar yang dapat digunakan secara mandiri adalah modul. Modul diartikan sebagai sebuah 
buku yang ditulis dengan tujuan agar peserta didik dapat belajar secara mandiri tanpa atau dengan bimbingan guru [3]. Sementara, dalam pandangan lainnya, modul dimaknai sebagai seperangkat bahan ajar yang disajikan secara sistematis, sehingga penggunanya dapat belajar dengan atau tanpa fasilisator atau guru [4]. Modul berbasis metakognisi dapat digunakan sebagai alternative media belajar yang mampu mengatasi keterbatasan ruang dan waktu belajar. Akan tetapi, guru SMA PGRI Tanjung Pandan belum pernah menggunakan modul fisika berbasis metakognisi dalam proses belajar mengajar.

Berdasarkan uraian di atas maka perlu dikembangkan modul fisika materi momentum, impuls, dan hukum kekekalan momentum berbasis metakognisi. Dimaksudkan untuk membantu guru dalam menerapkan metakognisi pada kegiatan belajar mengajar, mengatasi keterbatasan ruang dan waktu, serta membantu siswa mengembangkan metakognisinya sesuai dengan cara belajar siswa masingmasing.

\section{Kajian Pustaka}

\section{Pembelajaran Fisika Berbasis Metakognisi}

Fisika merupakan ilmu pengetahuan yang paling mendasar, karena berhubungan dengan perilaku dan struktur benda [5]. Fisika merupakan ilmu pengetahuan tentang fenomena alam, berupa kumpulan fakta, konsep, prinsip, teori, dan hukum, serta proses yang sistematik untuk memperoleh konsep-konsep, prinsip, teori, dan hukum yang kemudian dapat diuji kebenarannya. Siswa dilatih memecahkan masalah dengan metode ilmiah pada pembelajaran fisika. Metode ilmiah meliputi kegiatan mengidentifikasi masalah, menyusun hipotesis, memprediksi konsekuensi dari hipotesis, melakukan eksperimen untuk menguji prediksi, dan merumuskan hukum umum sederhana yang diorganisasikan dari hipotesis, prediksi, dan ekperimen.

Berdasarkan karakteristik mata pelajaran fisika, belajar fisika membutuhkan metakognisi tinggi. Untuk itu perlu adanya upaya penerapan dan pengenalan metakognisi kepada siswa. Beberapa cara dapat ditempuh untuk menerapkan metakognisi pada pembelajaran fisika. Menggunakan pengalaman sehari-hari (kontekstual), menghubungkan pengetahuan awal siswa dengan pengetahuan yang sedang dipelajari, menerapkan problem solving, mengadakan kegiatan laboratorium, dan menekankan kepada siswa untuk melakukan refleksi diri merupakan cara-cara yang dapat diterapkan untuk menerapkan metakognisi dalam pembelajaran. Tujuan dari penerapan metakognisi adalah agar siswa dapat menjadi pemikir-pemikir kritis yang selalu berpikir dalam menerapkan suatu motivasi internal untuk menjadi sadar, ingin tahu, teratur, penuh analisis, percaya diri, toleransi, dan bertanggungjawab ketika menyampaikan alternatife, jujur secara intelektual ketika menerima ide-ide orang lain sebagai kebenaran, maupun ketika tertantang oleh keadaan.

\section{Metakognisi}

Istilah metakognisi dalam bahasa Inggris dinyatakan dengan metacognition, berasal dari dua kata yang dirangkai yaitu meta dan kognisi atau cognition. Istilah "meta" berasal dari bahasa yunani yang dalam bahasa inggris diterjemahkan dengan after, beyond, with, adjacent, yang merupakan suatu presif yang digunakan untuk menunjukkan pada suatu abstraksi dari suatu konsep. Sedangkan cognition berasal dari bahasa latin yaitu cognoscere, yaitu berarti mengetahui (to know) dan mengenal (to recognize). Kognisi disebut juga gejala-gajala pengenalan, merupakan "the act or proses of knowing including both awareness and judgment". Sedangkan kemampuan metakognisi mencakup aspek kognisi [6].

Metakognisi merupakan suatu istilah yang diperkenalkan oleh Flavell pada tahun 1976 dan menimbulkan banyak perdebatan pada pendefinisiannya. Hal ini berakibat bahwa metakognisi tidak selalu sama didalam berbagai macam bidang penelitian psikologi dan juga tidak dapat diterapkan pada satu bidang psikologi saja. Namun demikian, pengertian metakognisi yang dikemukakan oleh para peneliti bidang psikologi, pada umumnya memberikan penekanan pada kesadaran berpikir seseorang tentang proses berpikirnya sendiri.

Berdasarkan beberapa pengertian metakognitif beberapa ahli di atas disimpulkan bahwa metakognisi adalah suatu kesadaran tentang kognitif kita sendiri, bagaimana kognitif kita bekerja serta bagaimana mengaturnya. Kemampuan ini sangat penting terutama untuk keperluan efisiensi penggunaan kognitif kita dalam menyelesaikan masalah. Secara ringkas metakognitif dapat diistilahkan sebagai thinking about thingking.

\section{Modul}

Modul dimaknai sebagai seperangkat bahan ajar yang disajikan secara sistematis, sehingga pengunanya dapat belajar dengan atau tanpa fasilitator atau guru. Dengan demikian, sebuah modul harus dapat dijadikan bahan ajar sebagai pengganti fungsi pendidikan. Jika pendidikan mempunyai fungsi menjelaskan sesuatu, maka modul harus mampu menjelaskan sesuatu dengan bahasa yang mudah 
diterima peserta didik sesuai dengan tingkat pengetahuan dan usianya [7].

Terdapat lima karakteristik dari bahan ajar. Pertama, modul merupakan unit (paket) pengajaran terkecil dan lengkap. Kedua, modul memuat rangkaian kegiatan belajar yang direncanakan dan sistematis. Ketiga, modul memuat tujuan belajar (pengajaran) yang dirumuskan secara eksplit dan spesifik. Keempat, modul memungkinkan siswa belajar sendiri (independent), karena modul memuat bahan yang bersifat self-instructional. Kelima, modul adalah realisasi pengakuan perbedaan individual, yakni salah satu perwujudan pengajaran individual.

\section{Metode Penelitian/Eksperimen}

Pengembangan Modul Fisika ini sesuai dengan langkahlangkah Research and Development (R\&D). Produk yang dihasikan dalam penelitian ini adalah bahan ajar Modul, oleh karena itu pengembangan ini juga disesuaikan dengan langkah-langkah pembuatan Modul yang ada dalam Depdiknas.

Produk yang dikembangkan divalidasi oleh dua dosen sebagai ahli materi, dua dosen sebagai ahli media, dan dua orang guru SMA. Setelah produk direvisi sesuai dengan masukan dari para ahli kemudian diujicobakan pada siswa kelas XI. Data penilaian oleh ahli dan siswa berupa nilai kualitatif yang akan dirubah menjadi nilai kuantitatif skala Likert.

\section{Hasil Penelitian dan Pembahasan}

Hasil penelitian meliputi potensi dan masalah, pengumpulan data, desain produk, validasi desain, revisi desain, uji coba produk, dan yang terakhir revisi produk.

I. Dari hasil pengamatan dapat diketahui bahwa terdapat permasalahan dalam pembelajaran fisika untuk siswa, yaitu:

a. Metakognisi kurang mendapat perhatian dari guru. Sejauh ini guru lebih banyak terfokus pada penguasaan kognisi siswa.

b. Guru membutuhkan modul berbasis metakognisi untuk mengatasi keterbatasan penerapan metakognisi pada kegiatan belajar mengajar di kelas.

c. Siswa membutuhkan modul berbasis metakognisi untuk membantu mengaktifkan metakognisinya.

d. Siswa membutuhkan modul berbasis metakognisi yang dapat digunakan secara mandiri atau tanpa guru.

2. Memperhatikan beberapa permasalahan dalam pembelajaran, maka desain modul materi momentum dan impuls berbasis metakognisi untuk siswa kelas XI SMA/MA disusun dengan kriteria sebagai berikut:

a. Halaman sampul yang menarik

b. Memuat Kata pengantar.

c. Memuat Daftar isi.

d. Memuat Peta konsep.

e. Memuat deskripsi, apersepsi, dan motivasi singkat.

f. Memuat petunjuk penggunaan modul.

g. Memuat Kompetensi.

h. Memuat Indikator pencapaian materi.

i. Memuat cek kemampuan.

j. Terdapat judul pada awal pembahasan materi.

k. Terdapat tujuan pembelajaran dan rencana pembelajaran pada awal pembahasan materi.

1. Memuat Uraian materi dan contoh.

m. Memuat Latihan atau tugas.

n. Memuat rangkuman dari materi momentum, impuls dan hukum kekekalan momentum.

o. Memuat tes formatif pada modul yang bertujuan untuk mengukur kemajuan belajar siswa dalam satu unit pembelajaran.

p. Ada umpan balik dan tindak lanjut.

q. Memuat lembar portofolio.

r. Memuat Glosarium.

s. Kunci jawaban diberikan agar siswa dapat mengukur kemampuan diri sendiri.

t. Memuat daftar pustaka

3. Validasi dan Revisi Desain

a. Validasi desain

Penilaian kualitatif produk dilaksanakan oleh dua ahli materi, dua ahli media, dan dua guru fisika SMA/MA dengan mengisi lembar penilaian modul yang disediakan. Berdasarkan penilaian oleh dua ahli materi dengan persentase $80,62 \%$, dua ahli media dengan persentase $81,25 \%$, dan dua guru fisika SMA/MA dengan persentase $77,78 \%$, maka modul yang dikembangkan memenuhi kriteria sangat baik (SB). Selain memberikan penilaian, ahli juga memberikan masukan-masukan secara tertulis sebagai data kualitatif.

b. Uji pengguna (siswa)

Berdasarkan hasil analisis uji pengguna diperoleh persentase sebesar $87,36 \%$ sehingga dapat disimpulkan bahwa produk ini tergolong dalam 
kategori sangat baik (SB) untuk digunakan sebagai media pembelajaran fisika.

\section{Kesimpulan}

Simpulan yang diperoleh dari penelitian pengembangan ini adalah :

I. Telah dikembangkan modul fisika materi momentum, impuls dan hukum kekalan momentum berbasis metakognisi yang dapat dijadikan sebagai media pembelajaran.

2. Kualitas modul fisika materi momentum dan impuls berbasis metakognisi yang telah dikembangkan memiliki kualitas sangat baik (SB), berdasarkan penilaian oleh dua ahli materi dengan persentase $80,62 \%$, penilaian dua ahli media dengan persentase $81,25 \%$, dan penilaian dua guru fisika SMA/MA dengan persentase 77,78\%. Di samping itu berdasarkan penilaian uji pengguna (siswa) diperoleh persentase sebesar 87,36\% dengan kategori sangat baik $(\mathrm{SB})$.

\section{Kepustakaan}

[I] Arsyad, A. (2013). Media Pembelajaran. Jakarta: PT Raja Grafindo Persada.

[2] Hamid, H. D. (2013). Pengembangan Sistem Pendidikan Di Indonesia. Bandung: CV Pustaka Setia.

[3] Depdiknas. (2008). Panduan Pembelajaran Bahan Ajar. Jakarta: Direktorat Jenderal Pendidikan Menengah dan Umum.

[4] Andi, P. (20II). Panduan Kreatif Membuat Bahan Ajar Inovatif. Yogyakarta: DIVA Preaa.

[5] Giancoli, D. C. (200I). Fisika Jilid I. Jakarta: Erlangga.

[6] Kuntjojo. (2009). Metakognisi dan Keberhasilan Belajar Peserta Didik. http://ebekunt.wordpress.com.I2/04/2009/metakognisidan-keberhasilan-belajar-peserta-didik/. Diakses 7 Mei 2014.

[7] Andi, P. (20I I). Panduan Kreatif Membuat Bahan Ajar Inovatif. Yogyakarta: DIVA Preaa. 